\title{
Differential Expression of Complement C3 and C4 in the Human Kidney
}

\author{
Thomas R. Welch, * Linda S. Beischel, * and David P. Witte* \\ Departments of ${ }^{*}$ Pediatrics and ${ }^{\ddagger}$ Pathology, University of Cincinnati, and Divisions of ${ }^{*}$ Nephrology and ${ }^{\ddagger}$ Pathology, \\ Children's Hospital Research Foundation Cincinnati, Ohio 45229-2899
}

\begin{abstract}
Complement activation is associated with a variety of immunologically-mediated renal diseases. Proximal tubular epithelial cells in situ constitutively express messenger RNA for C4 of the complement system. These same epithelial cells in culture have been reported to contain message for $\mathrm{C} 3$ and to secrete this protein when stimulated by IL-2. The present study compared the in situ localization of $\mathrm{C} 3$ and $\mathrm{C} 4$ message in parallel in a variety of renal biopsy and nephrectomy specimens. All adequate tissue samples $(n=23)$ had C4 mRNA throughout in the cortical tubular epithelium. Although C3 message was also expressed in tubular epithelial cells, there was much greater variation in its distribution. mRNA for $\mathrm{C} 3$ was not detected in histologically normal specimens $(n=4)$ either by in situ or Northern hybridization. Focal C3 message correlated with focal histologic abnormalities (e.g., focal glomerulosclerosis), while more generalized $\mathrm{C} 3$ signal occurred in specimens with more diffuse inflammatory processes (e.g., SLE). Infiltrating inflammatory cells and cells of the glomeruli were uniformly negative for C3 (and C4) message. Tubular C3 and C4 mRNA appeared to be translated, since selected specimens showed cytoplasmic staining by monoclonal antibodies to $\mathrm{C} 3 \mathrm{c}$ and $\mathrm{C4c}$. These observations are consistent with the hypothesis that local production of inflammatory mediators could induce $\mathbf{C} 3$ synthesis in the renal interstitium, with the possibility that subsequent complement activation could enhance the pathogenic process. (J. Clin. Invest. 1993. 92:1451-1458.) Key words: complement 3 - complement $4 \cdot$ kidney tubules $\cdot$ gene expression • glomerulonephritis
\end{abstract}

\section{Introduction}

Activation of the complement system generates a highly regulated cascade of inflammatory mediators that promote host defense from foreign organisms. Unfortunately, these same mediators may also contribute to host tissue injury. Complement activation is associated with immunologically mediated renal diseases such as SLE, membranoproliferative glomerulonephri-

Address correspondence and reprint requests to Thomas R. Welch, M.D., Children's Hospital Research Foundation, Division of Nephrology, Elland and Bethesda Avenues, Cincinnati, OH 45229-2899.

Received for publication 30 November 1992 and in revised form 8 March 1993.

J. Clin. Invest.

(c) The American Society for Clinical Investigation, Inc.

0021-9738/93/09/1451/08 $\$ 2.00$

Volume 92, September 1993, 1451-1458 tis (MPGN) ${ }^{1}$, and acute poststreptococcal glomerulonephritis. The evidence for this includes systemic complement component depletion (1), the presence of circulating complement activation products $(2)$, and the deposition of complement components with other immune reactants in the kidney (3).

A number of biologically active proteins central to the inflammatory response can be synthesized at their site of action. Tissue kallikrein and histamine, for example, are released in the lung after allergen challenge and play an important role in asthma (4). Synovial tissues have also been shown to release cytokines and other peptides during active arthropathies (5). Although the liver is the presumed source of most circulating complement components in humans, the possibility exists that local synthesis of these proteins plays a role in some inflammatory conditions. In at least one animal model of complementmediated disease, the MRL lpr/lpr mouse, progressive injury is associated with upregulated extrahepatic transcription of the genes for components C2, C3, C4, and B (6). The apparent tissue-specific nature of this regulation further supports the possibility of a local role and the potential for its specific pharmacologic modulation.

In a previous study (7), we demonstrated the constitutive expression of $\mathrm{C} 4 \mathrm{mRNA}$ by human renal tubular epithelial cells in situ. In the current study, we examine the localization of C3 message in the human kidney.

\section{Methods}

Tissues. Fresh human kidney tissue was obtained at the time of nephrectomy or open or percutaneous renal biopsy, snap frozen in liquid nitrogen, and stored at $-70^{\circ} \mathrm{C}$. Non-tumor-containing areas of kidneys removed because of Wilms' tumor, as well as renal biopsy specimens which were obtained because of minimal asymptomatic urinary abnormalities, were considered "normal" tissues on the basis of negative findings by light, immunofluorescence, and electron microscopy.

Nucleic acid probes. The plasmid pHLC3.11 containing a 4.3-kb C3 cDNA insert was obtained from the American Type Culture Collection (Rockville, MD) (8). A 320-bp fragment containing exons 28 and 29 was amplified by the polymerase chain reaction in a thermal cycler (Perkin-Elmer Cetus Instruments, Norwalk, CT) to contain terminal BamHI and KpnI restriction sites, and subcloned into pBluescript II (Stratagene Inc., La Jolla, CA). Transcription in the presence of ${ }^{35} \mathrm{~S}$ UTP (Amersham Corp., Arlington Heights, IL), using T3 or T7 RNA polymerase, yielded single-stranded, radiolabeled, antisense or sense probes, respectively, for C3 message. RNA probes for C4 were generated as described previously (7). Radiolabeled probes were gel purified or passed over columns (Quick Spin; Boehringer-Mannheim Corp., Indianapolis, IN) to remove unincorporated nucleotide before in situ hybridization.

1. Abbreviation used in this paper: MPGN, membranoproliferative glomerulonephritis. 
Northern analyses. Total RNA was prepared from frozen tissue by guanidinium isothiocyanate, acid phenol, and chloroform extractions (9). The RNA was separated by electrophoresis in agarose, transferred to nitrocellulose, and hybridized with ${ }^{32} \mathrm{P}$-labeled DNA probes for $\mathrm{C4}$ and actin as previously described (7). In addition, a 1.8-kb fragment obtained by ClaI and SalI digestion of pHLC3.11 was used to probe for C3 message.

In situ hybridization method. Cryostat sections ( $12 \mu \mathrm{m})$ of frozen tissue were air dried onto microscope slides coated with 3-aminopropyltriethoxysilane (Sigma Immunochemicals, St. Louis, MO). After fixation for $1 \mathrm{~h}$ in $4 \%$ paraformaldehyde in phosphate-buffered saline, slides were washed with $70 \%$ ethanol and $2 \times$ SSC $(20 \times$ SSC is $3 \mathrm{M}$ $\mathrm{NaCl}, 0.3 \mathrm{M} \mathrm{Na}_{3} \mathrm{C}_{6} \mathrm{H}_{5} \mathrm{O}_{7} \cdot 2 \mathrm{H}_{2} \mathrm{O}, \mathrm{pH} 7$ ). Sections were digested for 5 min at room temperature in $20 \mu \mathrm{g} / \mathrm{ml}$ proteinase $\mathrm{K}$ in $0.2 \mathrm{M}$ Tris $\mathrm{pH}$ 8.3. After a wash in $2 \times$ SSC, sections were acetylated in $0.25 \%$ acetic anhydride in $0.1 \mathrm{M}$ triethanolamine, $\mathrm{pH} 8(\mathrm{vol} / \mathrm{vol})$ for $10 \mathrm{~min}$, dehydrated in graded ethanols, and air dried. Sections were prehybridized at $42^{\circ} \mathrm{C}$ for $15 \mathrm{~min}$ by overlaying $50 \mu \mathrm{l}$ of a solution of $50 \%$ formamide (E.M. Science, Cherry Hill, NJ), $2 \times$ SSC, $1 \times$ Denhardt's solution, $10 \%$ dextran sulfate, $750 \mu \mathrm{g} / \mathrm{ml}$ yeast transfer RNA, $750 \mu \mathrm{g} / \mathrm{ml}$ herring sperm DNA, $5 \mathrm{mM}$ DTT, $100 \mu \mathrm{g} / \mathrm{ml} \mathrm{BSA}$, and $74 \mu \mathrm{M}$ 4-thiouridine $5^{\prime}$ monophosphate (thio-UMP) (Sigma Immunochemicals). Fresh prehybridization solution $(25 \mu \mathrm{l})$, which lacked thio-UMP but contained $2 \times 10^{7} \mathrm{cpm} / \mathrm{ml}$ of ${ }^{35} \mathrm{~S}$-labeled RNA probe, was added to each section and allowed to hybridize overnight at $42^{\circ} \mathrm{C}$ under a coverslip sealed with rubber cement. After the coverslips were removed and the sections rinsed, unhybridized probe was digested with a mixture of $50 \mu \mathrm{g} / \mathrm{ml}$ RNase A and $100 \mu / \mathrm{ml}$ RNase T1 (Boehringer-Mannheim) for $30 \mathrm{~min}$ at $37^{\circ} \mathrm{C}$. Sections were washed in $50 \%$ formamide in $1 \times \mathrm{SSC}$ at $50^{\circ} \mathrm{C}$ and, most stringently, with $0.1 \times \mathrm{SSC}$ at $55^{\circ} \mathrm{C}$. All washes contained 1 mM DTT. The slides were then dehydrated, dipped in Kodak NTB2 emulsion, exposed for $10-20 \mathrm{~d}$ at $4^{\circ} \mathrm{C}$, developed, and counterstained with hematoxylin and eosin.

In situ experimental design. Sequential sections from each tissue sample were probed simultaneously with ${ }^{35} \mathrm{~S}$-labeled antisense riboprobes to identify $\mathrm{C} 3$ and $\mathrm{C} 4$ messages, and with a sense riboprobe for C3 as a negative control. A renal sample from a patient with MPGN (Tissue 3 from Table I, reference 7) was examined concurrently with each group of patient samples as a positive control. In situ results for 23 renal specimens ( 6 surgical and 17 biopsy) in which adequate tissues were available were assigned after independent review of all materials by three investigators. Tissue was considered inadequate if no renal

Table I. Human Kidney C3 Gene Expression

\begin{tabular}{|c|c|c|c|}
\hline Case number & Tissue diagnosis* & C3 in situ & C3 distribution \\
\hline $90-5339$ & Normal (transplant biopsy) & Negative & - \\
\hline $91-5209$ & Normal (nontumor area of Wilms' nephrectomy) & Negative & - \\
\hline $91-1076$ & Normal (nontumor area of Wilms' nephrectomy) & Negative & - \\
\hline $88-4069$ & Normal (nontumor area of neuroblastoma nephrectomy) & Negative & - \\
\hline $88-500 \mathrm{~B}$ & End-stage crescentic glomerulonephritis (MPGN II) & Positive & Diffuse \\
\hline $90-5082$ & Diffuse proliferative glomerulonephritis (SLE) & Positive & Focal \\
\hline $89-1260$ & Diffuse proliferative glomerulonephritis (SLE) & Positive & Diffuse \\
\hline $91-3407$ & Severe glomerulonephritis with crescents (HSP) & Positive & Focal \\
\hline $91-2029$ & Severe glomerulonephritis with crescents (HSP) & Positive & Focal \\
\hline $83-569$ & $\begin{array}{l}\text { Immune complex glomerulonephritis (secondary to } \\
\text { bacteremia) }\end{array}$ & Positive & Diffuse \\
\hline $92-1951$ & Medullary cystic disease with tubular atrophy & Positive & Focal \\
\hline $88-3275$ & Rapidly progressive glomerulonephritis & Positive & Focal \\
\hline $90-5048$ & $\begin{array}{l}\text { Focal segmental glomerulosclerosis with focal tubular } \\
\text { atrophy }\end{array}$ & Positive & Focal \\
\hline $88-5493$ & $\begin{array}{l}\text { Focal segmental glomerulosclerosis with focal tubular } \\
\text { atrophy }\end{array}$ & Positive & Focal \\
\hline $90-133$ & $\begin{array}{l}\text { Focal interstitial infiltrate (congenital nephrotic } \\
\text { syndrome) }\end{array}$ & Positive & Focal \\
\hline $91-1679$ & $\begin{array}{l}\text { Focal interstitial infiltrate and tubular atrophy } \\
\text { (congenital nephritis) }\end{array}$ & Positive & Focal \\
\hline $90-2417$ & $\begin{array}{l}\text { Focal interstitial nephritis (nontumor area from Wilms' } \\
\text { nephrectomy) }\end{array}$ & Positive & Focal \\
\hline $91-540$ & $\begin{array}{l}\text { Interstitial nephritis (nontumor area from Wilms' } \\
\text { nephrectomy) }\end{array}$ & Positive & Diffuse \\
\hline $88-1182$ & $\begin{array}{l}\text { Interstitial nephritis (nontumor area from Wilms' } \\
\text { nephrectomy) }\end{array}$ & Positive & Focal \\
\hline $75-315$ & Focal interstitial nephritis (HUS) & Positive & Focal \\
\hline $75-268$ & Interstitial infiltrate (transplant biopsy) & Positive & Focal \\
\hline $77-378$ & Severe chronic transplant rejection & Positive & Diffuse \\
\hline $92-1620$ & Interstitial nephritis with tubulitis (transplant rejection) & Positive & Focal \\
\hline
\end{tabular}

* MPGN II, MPGN type II, HSP, Henoch-Schonlein purpura; HUS, hemolytic uremic syndrome.

* The signal for C3 message was considered diffuse if epithelial cells of $50 \%$ of cortical tubules were positive. If $<50 \%$ of cortical tubules were positive for C3 message, then the signal was considered focal. A focal distribution of C3 message was invariably associated with focal interstitial infiltrate or focal tubular atrophy. 
cortex was present, since $\mathrm{C} 4$ message was previously localized to cortical tubules (7), or if the tissue appeared generally degraded by hematoxylin and eosin staining. The pattern of tubular RNA expression was defined as "diffuse" if signal was present in most areas of the section and in $\geq 50 \%$ of cortical tubules. The distribution was considered "focal" if it appeared confined to specific areas of the section and involved $<50 \%$ of cortical tubules.

Immunohistochemistry. Sections of frozen liver or kidney tissue were reacted with monoclonal antibodies to $\mathrm{C} 3 \mathrm{c}, \mathrm{C} 3 \mathrm{~d}, \mathrm{C} 4 \mathrm{c}$, and $\mathrm{C} 4 \mathrm{~d}$ (Quidel, San Diego, CA) and stained with a peroxidase-conjugated second antibody according to the protocol supplied with the Vectastain Elite $\mathrm{ABC}$ (avidin-biotin-complex) kit by Vector Laboratories, Inc. (Burlingame, CA). Monoclonal antibodies were used at a dilution of 1:400 or greater. The substrate diaminobenzidine (Sigma Immunochemicals) was added in a solution containing $1 \%$ nickel sulfate (Malinkrodt, St. Louis, MO) to intensify the reaction. The tissue was then counterstained with nuclear fast red. Endogenous peroxidase activity was blocked by previous incubation in $0.3 \%$ hydrogen peroxide in methanol. Antibody was omitted from some sections as a negative control.

\section{Results}

Northern analysis. Four specimens of whole kidney tissue were available for RNA extraction and analysis. Of these, two were normal tissue from the uninvolved areas of organs resected for Wilms' tumor. The other two represented end-stage organs from patients with MPGN and transplant rejection.

Fig. 1 is a Northern blot from these samples, hybridized with the $\mathrm{C} 3$ probe. No signal was detected in the normal kidneys. The RNA from diseased kidneys, as well as from normal liver, yielded a signal of appropriate size for C3 message. All samples produced signals of equal intensity when hybridized to a human alpha-actin probe.

In situ hybridization. Four samples of kidney tissue in which no histologic abnormalities were detected had no C3 message by in situ hybridization. As with all kidney tissue examined, however, these samples showed generalized cortical tubular C4 message. 19 samples with various degrees of histologic

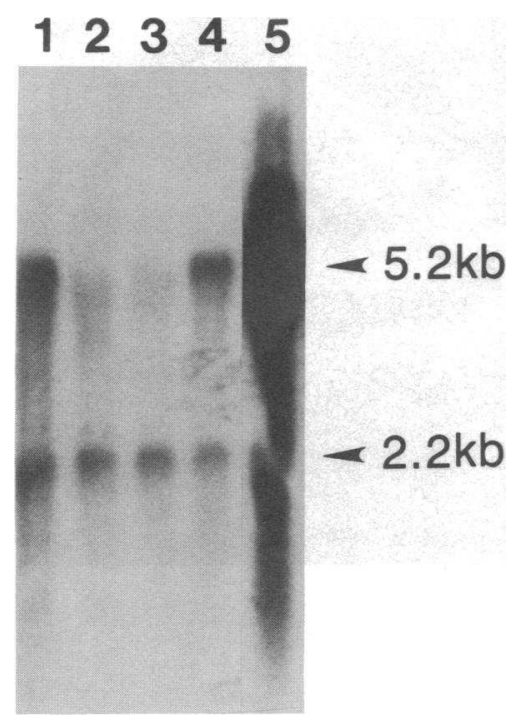

abnormality were positive for C3 mRNA by in situ hybridization. In general, the signal in positive cases was restricted to the proximal tubular epithelium. This signal was diffuse in some generalized inflammatory processes such as SLE (Fig. 2, $A-D$ ), but was usually focal in processes with a more limited distribution of histologic abnormality (Fig. 2, $E$ and $F$ ). There was a complete lack of glomerular or vessel-wall signal. Occasionally, a tubularized crescent (composed of epithelial cells) showed C3 message (Fig. $2 B$ ).

By sequentially examining identical sections with dark field and bright field illumination, it was possible to correlate the distribution of C3 message to histology with considerable precision. Although the tubules that were adjacent to inflammatory infiltrates were generally positive for $\mathrm{C} 3$ message, the signal was clearly in the epithelium and not in the infiltrating cells (Fig. 2, $G$ and $H$ ). C4 mRNA expression was always generalized in cortical epithelial cells, in a pattern clearly different from that of $\mathrm{C} 3$ (Fig. 3, $A-F$ ) (7).

Immunohistochemistry. A representative renal specimen (case 91-540, Table I), which had a diffuse distribution of C3 and C4 mRNA in renal tubular epithelial cells by in situ hybridization, also had specific staining for $\mathrm{C} 3$ and $\mathrm{C} 4$ protein in the cytoplasm of these same cells by immunohistochemistry (Fig. 4). Monoclonal anti-C $3 \mathrm{c}$ and anti-C4c were used, since these antigenic determinants should be available on intact $\mathrm{C} 3$ and C4. Monoclonal anti-C3d and anti-C4d staining was used for comparison, since these determinants remain on extracellular deposits of these components after complement activation. With anti-C3c and anti-C4c (Fig. 4, E-H), only tubules were stained, while glomerular and infiltrating cells were generally negative. In contrast, glomeruli, tubules, and blood vessels were stained by anti-C3d and anti-C4d (Fig. 4, $I$ and $J$ ). Previous studies (7) using polyclonal antisera produced results similar to those with monoclonal anti-C4d and failed to detect cytoplasmic $\mathrm{C} 4$ protein in the renal tubular epithelium or in hepatocytes of the liver (a known source of C4). Examination of liver sections with monoclonal anti-C4d and anti-C3d also showed no staining of hepatocytes while the cytoplasm of these cells was clearly stained by anti-C4c and anti-C3c (Fig. 4, $A-$ $D)$. Thus, for both $\mathrm{C} 3$ and $\mathrm{C} 4, \mathrm{mRNA}$ and protein seem to colocalize as long as antisera to determinants exposed on the intact complement components are used.

\section{Discussion}

For most immune-mediated glomerulonephritides, complement components are present with other immune reactants in the glomerular lesions (3). In some cases, these components may represent complexes formed in the circulation and trapped in the kidney; complement is probably deposited on these complexes in the circulation. Alternatively, complexes may form in the glomerulus and react with available complement locally. In either scenario, the deposited complement has been presumed to derive from the circulation, after synthesis in the liver.

A number of extrahepatic tissues and cell lines have been shown to syntherize specific complement components, both in vivo (7) and in vitro (10-12). In particular, cultured peripheral mononuclear cells can be induced to express both RNA and protein for most complement components. Although it is 

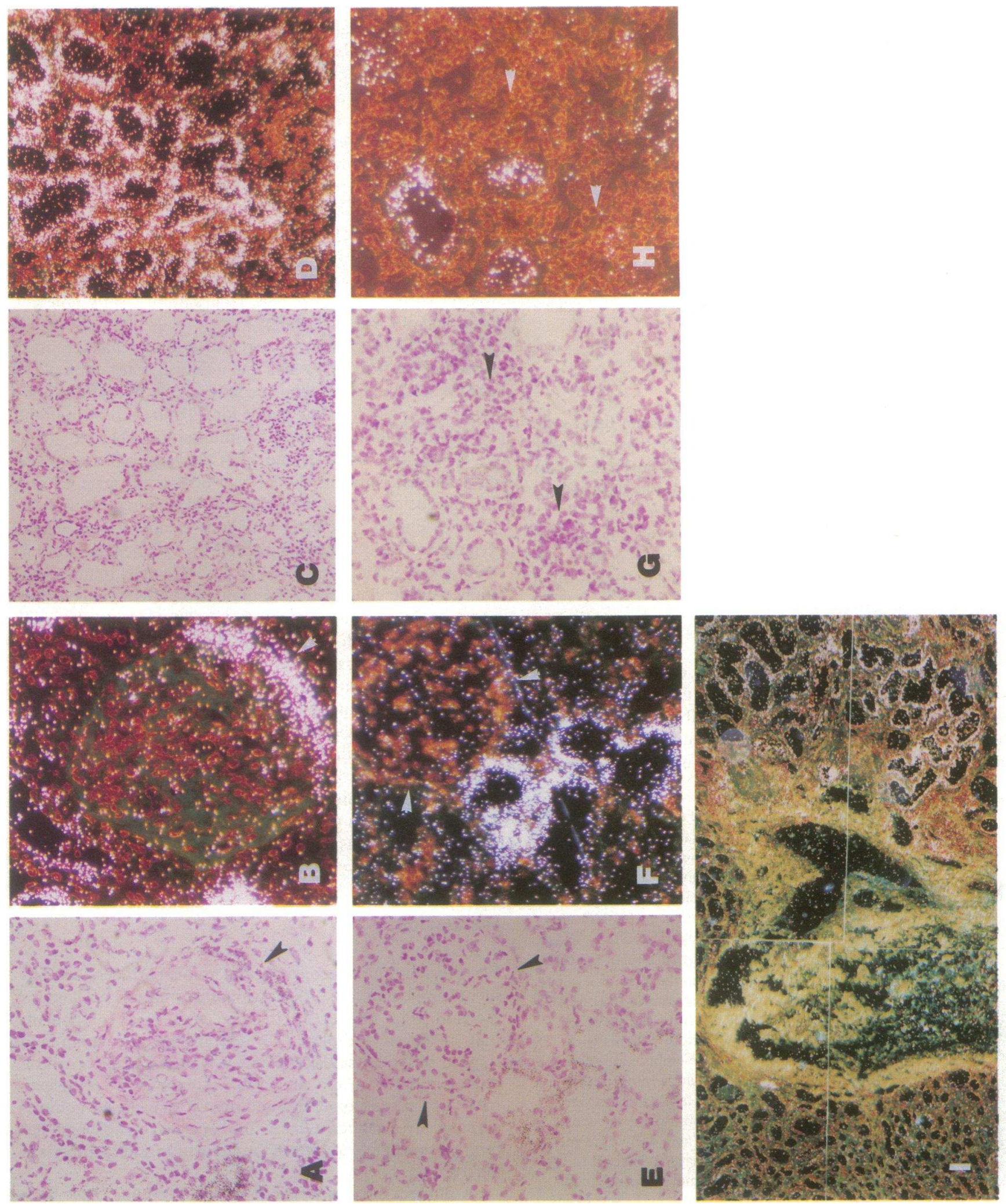

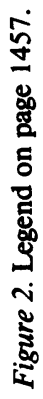



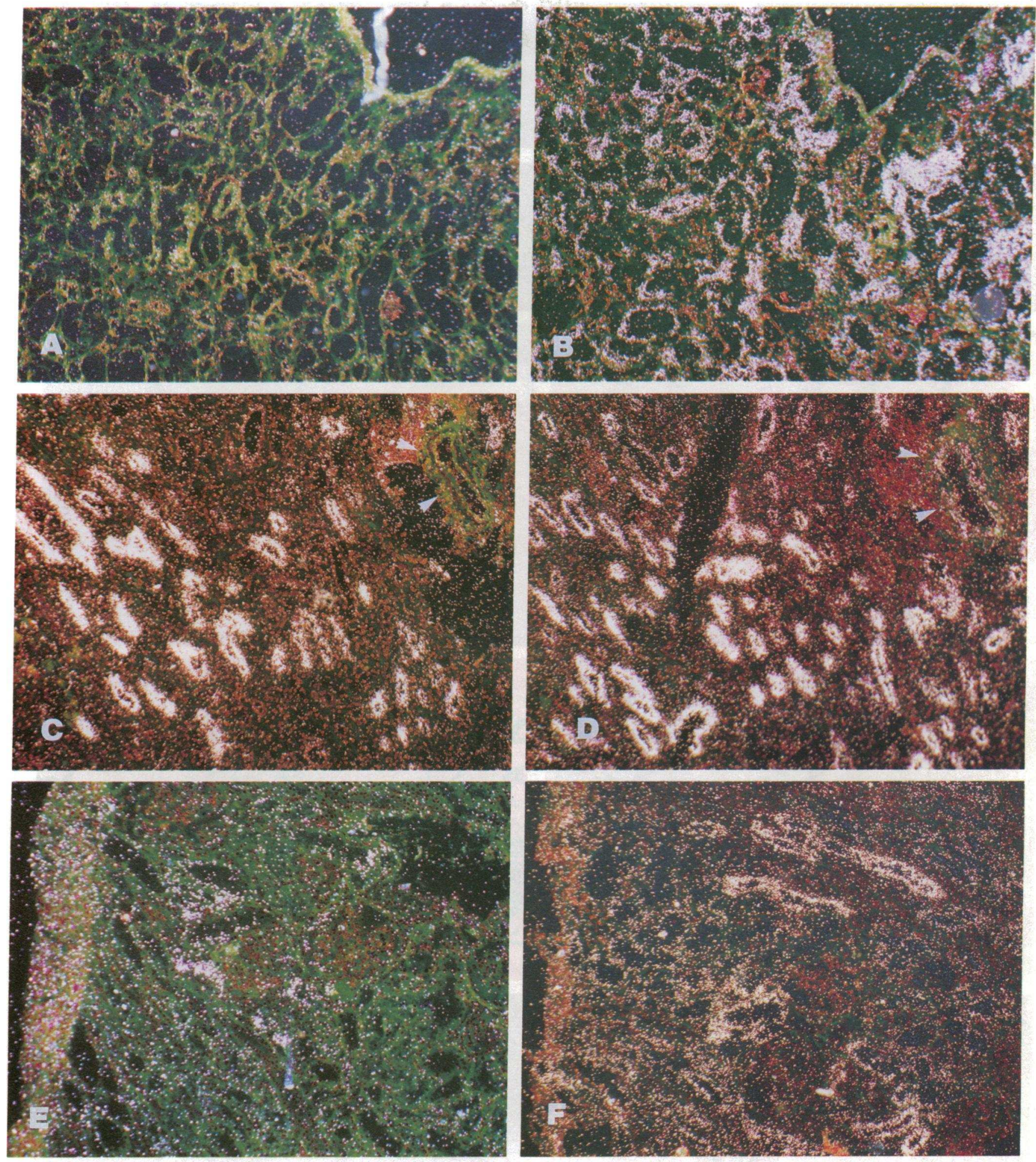

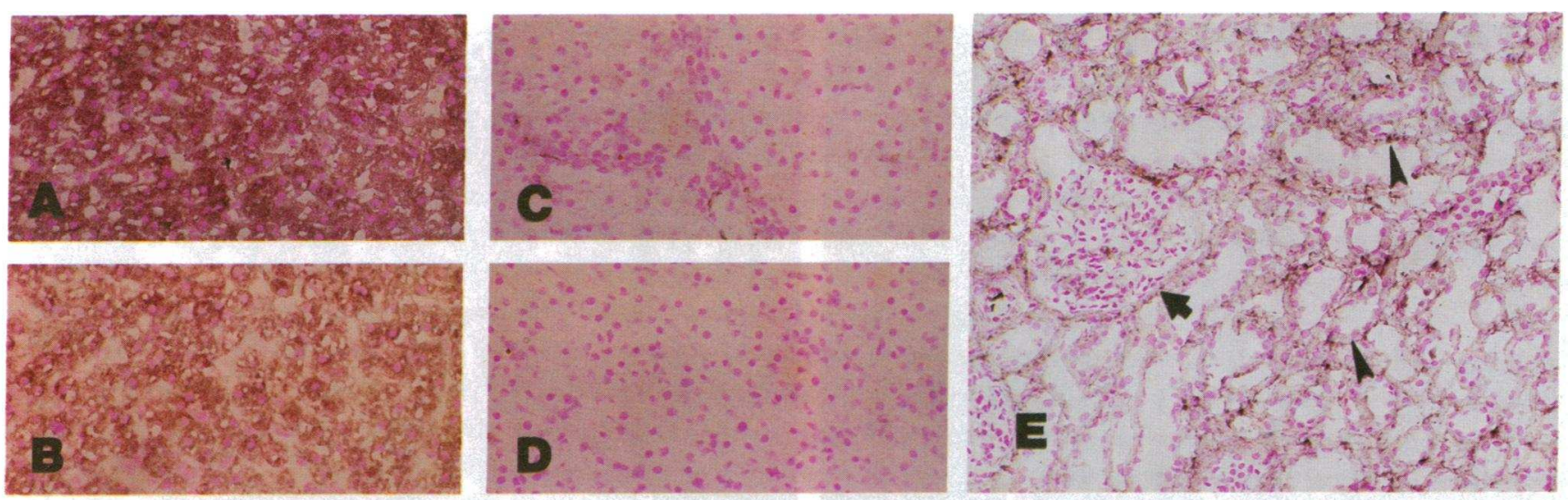

$x^{2}=2 x$
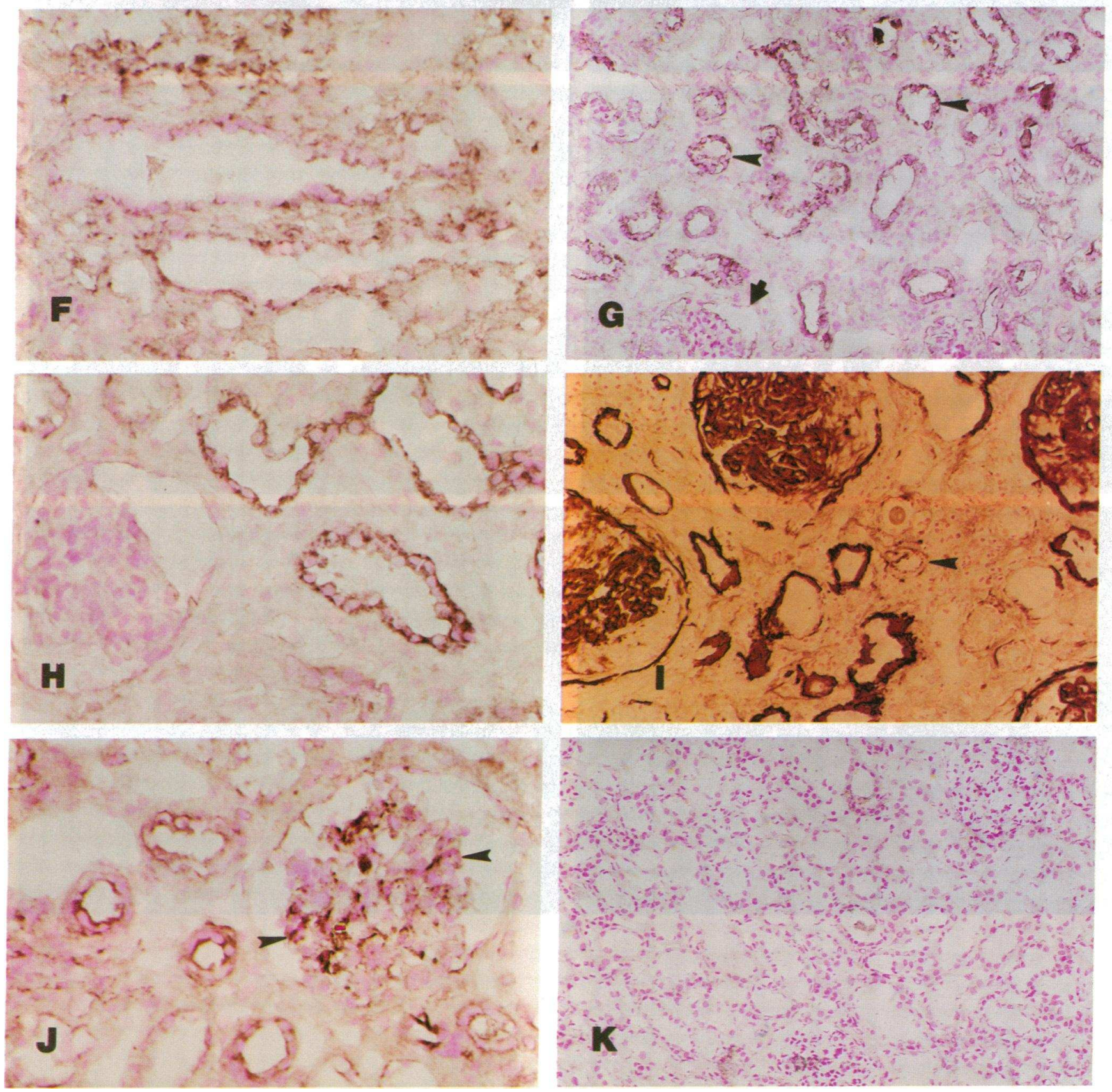

Figure 4. Legend on facing page. 
tempting to speculate that such local synthesis could be relevant to renal inflammatory disease, there have been no data to support such a possibility until recently.

Studies in our laboratory have shown that mRNA for C4 can be detected in samples of both normal and diseased human kidneys. By in situ hybridization, we were able to localize this message to the proximal tubular epithelium. The signal was not identified in glomeruli, and was uniform in intensity and distribution throughout the samples studied (Fig. 2, $B-D$ in reference 7). These findings did not support a contribution of local C4 synthesis to renal disease; a role in local immunity could not be excluded (13).

We next examined $\mathrm{C} 3$ gene expression, in light of the central place this protein holds in the inflammatory cascade. Our preliminary studies by Northern analysis suggested that mRNA for this component was not present in healthy kidneys, but was demonstrable in organs affected by a variety of nephritides. Subsequent investigations by Brooimans et al demonstrated both $\mathrm{C} 3$ message and functionally active $\mathrm{C} 3$ protein in cultured human proximal tubular epithelial cells. C3 synthesis in this system could be upregulated by IL-2. These workers speculated that such regulated local synthesis could be important in immune complex disease, but did not study any cells of glomerular origin (14).

Our data confirm in vitro studies that suggest human kidney tissue can be a source of $\mathrm{C} 3$. The absence of $\mathrm{C} 3$ message in normal kidney tissue, by both Northern analysis and in situ hybridization, suggests that this component is differentially regulated in comparison to $\mathrm{C} 4$. In addition, immunohistochemical examination of representative tissues confirms that the C3 and $\mathrm{C} 4$ message detected in situ is translated into protein.

Not only is $\mathrm{C} 3$ expression limited to abnormal kidneys, its cellular localization is usually focal and restricted to areas of inflammation. As is the case for $\mathrm{C} 4$, tubular epithelial cells are the source of this C3 mRNA. There is no evidence of glomeru- lar message. In addition, there is no evidence of C3 mRNA in vascular endothelium or in the infiltrating inflammatory cells themselves.

These data, then, do not support the hypothesis of a role for locally synthesized C3 in direct glomerular injury. They do, however, raise the possibility that such local synthesis contributes to interstitial renal disease, including the interstitial component of advanced glomerulonephritis. A variety of glomerulonephritides, especially those with a proliferative component, are associated with a marked peritubular inflammatory reaction (15). The glomerular mesangium synthesizes a number of growth factors and cytokines, both in vivo and in vitro (16, 17). At least one of these, IL-6, apparently can gain access to the glomerular circulation from the mesangium (17). In vitro studies have shown that cultured renal tubular epithelial cells can respond to cytokine stimulation with upregulation of $\mathrm{C} 3$ synthesis (14).

A reasonable hypothesis, consistent with our data, is that a glomerular inflammatory reaction induces $\mathrm{C} 3$ gene expression in the corresponding tubules. For example, Fig. 2, $E$ and $F$ illustrate the proximal tubule derived from an injured glomerulus that is both positive for $\mathrm{C} 3$ message and shows peritubular inflammation. In the ammonia-rich peritubular interstitium, locally synthesized $\mathrm{C} 3$ could be amidated to $\mathrm{NH}_{3} \cdot \mathrm{C} 3$, as recently proposed by Nath and Hostetter (18). Fluid phase $\mathrm{NH}_{3} \cdot \mathrm{C} 3$ has stimulatory effects on polymorphonuclear leukocytes and monocytes that are greater than that of $\mathrm{C} 3 \mathrm{a}$ (19). Furthermore, $\mathrm{NH}_{3} \cdot \mathrm{C} 3$ can cleave $\mathrm{C} 3$ to $\mathrm{C} 3 \mathrm{~b}$, which is then available for deposition on surfaces. This cleavage also releases $\mathrm{C} 3 \mathrm{a}$, another potent inflammatory mediator.

If such a mechanism were operative, then specific antagonism of tubular $\mathrm{C} 3$ gene expression could play an important role in the treatment of some acute and chronic glomerulonephritides. Such an approach will require understanding of the elements responsible for this tissue-regulated gene expression.

Figure 2. Hematoxylin and eosin $(A, C, E$, and $G)$ and dark-field examination $(B, D, F, H$, and $I)$ of renal tissue hybridized in situ with antisense C3 riboprobe. Bright grains indicate positive signal. $(A$ and $B)$ Severe type II membranoproliferative glomerulonephritis with C3 in proximal tubules and a "tubularized" crescent (arrowheads); no signal in vessel or glomerular mesangium (case 88-500B, $\times 225$ ). $(C$ and $D$ ) Diffuse proliferative lupus glomerulonephritis with diffuse $C 3$ expression in proximal tubules (case 89-1260, $\times 111)$. $(E$ and $F)$ Focal segmental glomerulosclerosis with $\mathrm{C} 3$ expression restricted to the proximal tubule derived from a glomerulus with a single segmental lesion (arrowheads) (case 88-5493, $\times 111)$. ( $G$ and $H$ ) Henoch-Schonlein purpura glomerulonephritis with an extensive mononuclear inflammatory infiltrate (arrowheads) showing no $C 3$ signal despite obvious $C 3$ message in adjacent proximal tubules (case 91-3407, $\times 111$ ). (I) Composite view of a low power magnification of a section from the same patient as in $A$ and $B$. This demonstrates the localization of $C 3$ positive tubules to the renal cortex (right) with no signal coming from the medulla (left), or the large central blood vessel.

Figure 3. Comparison of $\mathrm{C} 3(A, C$, and $E)$ and $\mathrm{C} 4(B, D$, and $F)$ message expression in adjacent sections of renal tissues by dark field examination after in situ hybridization. Bright grains indicate positive signal. Sections from histologically normal kidney (case 91-1076, magnification $\times 111$ ) show no $C 3$ message $(A)$, while proximal tubules are uniformly positive for C4 message $(B)$. Sections from a kidney with interstitial nephritis and inflammatory infiltrate (case 91-540, $\times 111$ ) show a similar distribution of message for C3 $(C)$ and $C 4(D)$ in most tubules. Note the absence of signal from the blood vessel indicated with the arrowheads. Kidney sections from a patient with rapidly progressive glomerulonephritis (case 88-3275, $\times 111$ ) show a more focal distribution of $C 3$ message $(E)$, while most tubules are positive for $C 4$ message $(F)$.

Figure 4. Immunohistochemistry of normal human liver $(A-D)$ and kidney $(E-K)$, using monoclonal antibodies to human $C 3 \mathrm{c}(A, E$, and $F)$, $\mathrm{C} 4 \mathrm{c}(B, G$, and $H), \mathrm{C} 3 \mathrm{~d}(C$ and $I)$, and $\mathrm{C} 4 \mathrm{~d}(D$ and $H)$. The hepatocytes show diffuse cytoplasmic staining with antibody to the $C 3 \mathrm{c}$ and $C 4 \mathrm{c}$ determinants $(A$ and $B)$. The liver is negative for $\mathrm{C} 3 \mathrm{~d}(C)$ and $C 4 \mathrm{~d}(D)$. Antibody to $\mathrm{C} 3 \mathrm{c}$ in the kidney $(E)$ corresponds to the findings with in situ hybridization with the absence of staining in glomerulus (indicated by the arrow). There is diffuse cytoplasmic staining of some tubular epithelial cells (arrowheads) (case 91-540, $\times 111)$. A higher magnification $(F)(\times 225)$ view of the same kidney confirms this tubular epithelial distribution of staining. The $\mathrm{C} 4 \mathrm{c}$ antibody $(G)$ confirms the absence of protein in cells of the glomeruli (arrow), with diffuse cytoplasmic staining of some tubular epithelial cells (arrowheads) (case 91-540, $\times 111$ ). A high power view of the same kidney $(H)(\times 225)$ details the localization of staining to the cytoplasm of the tubular epithelia. The antibody to $\mathrm{C} 3 \mathrm{~d}$ labels the extensive glomerular deposits $(I)($ case $88-500 \mathrm{~B}, \times 225)$, as well as both the adjacent tubules and a single blood vessel (arrowhead). The C4d antibody $(J)$ labels the glomerular mesangium (arrowheads), as well as adjacent tubules. A low power $(\times 111)$ (obtained without the use of primary antibody) provides a control for these sections $(k)$. 
Note added in proof. Since this manuscript was submitted, Sacks et al. (1993. Immunology. 79:348-354), have reported C3 gene expression, both protein and message, in glomerular epithelial cells derived from normal kidneys and cultured in vitro. With the exception of crescents in an end-stage kidney, we have never observed messenger RNA for C3 or $\mathrm{C} 4$ in any human glomerular cells in situ.

\section{Acknowledgments}

The authors gratefully acknowledge the technical expertise of Kathy Saalfeld, Jean Snyder, and Terry Smith. Mrs. Barbara Pieper prepared the manuscript, and Dr. Alvin E. Davis III reviewed the manuscript and provided helpful discussion.

The work was partially supported by a grant from the Kidney Foundation of Greater Cincinnati.

\section{References}

1. West, C. D. 1984-1985. Complement activation in renal disease. Uremia Invest. 8:225-235.

2. Wyatt, R. J., J. Forristal, C. D. West, S. Sugimoto, and J. G. Curd. 1988. Complement profiles in acute post-streptococcal glomerulonephritis. Pediatr. Nephrol. 2:219-223.

3. Couser, W. G. 1985. Mechanisms of glomerular injury in immune-complex disease. Kidney Int. 28:569-583.

4. Christiansen, S. C., D. Proud, R. B. Sarnoff, U. Juergens, C. G. Cochrane, and B. L. Zuraw. 1992. Elevation of tissue kallikrein and kinin in the airways of asthmatic subjects after endobronchial allergen challenge. Am. Rev. Respir. Dis. 145:900-905.

5. Wood, N. C., J. A. Symons, E. Dickens, and G. W. Duff. 1992. In situ hybridization of IL-6 in rheumatoid arthritis. Clin. Exp. Immunol. 87:183-189.

6. Passwell, J., G. F. Schreiner, M. Nonaka, H. U. Beuscher, and H. R. Colten.

1988. Local extrahepatic expression of complement genes $\mathrm{C} 3$, factor $\mathrm{B}, \mathrm{C} 2$, and C4 is increased in murine lupus nephritis. J. Clin. Invest. 82:1676-1684.

7. Witte, D. P., T. R. Welch, and L. S. Beischel. 1991. Detection and cellular localization of human $\mathrm{C} 4$ gene expression in the renal tubular epithelial cells and other extrahepatic epithelial sources. Am. J. Pathol. 139:717-724.

8. deBruijn, M. H. L., and G. H. Fey. 1985. Human complement component C3: cDNA coding sequence and derived primary structure. Proc. Natl. Acad. Sci. USA. 82:708-712.

9. Chomczynski, P., and N. Sacchi. 1987. Single-step method of RNA isolation by acid guanidinium thiocyanate-phenol-chloroform extraction. Anal. Biochem. 162:156-159.

10. Whaley, K. 1980. Biosynthesis of the complement components and the regulatory proteins of the alternative complement pathway by human peripheral blood monocytes. J. Exp. Med. 151:501-516.

11. Kulics, J., H. R. Colten, and D. H. Perlmutter. 1990. Counter-regulatory effects of interferon- $\gamma$ and endotoxin on expression of the human $C 4$ genes. $J$. Clin. Invest. 85:943-949.

12. Lappin, D. F., D. Guc, A. Hill, T. McShane, and K. Whaley. 1992. Effect of interferon- $\gamma$ on complement gene expression in different cell types. Biochem. J. 281:437-442.

13. Feucht, H. E., J. Zwirner, D. Bevec, M. Lang, E. Felber, G. Riethmuller, and E. H. Weiss. 1989. Biosynthesis of complement C4 messenger RNA in normal human kidney. Nephron. 53:338-342.

14. Brooimans, R. A., A. P. A. Stegmann, W. T. van Dorp, A. A. J. van der Ark, F. J. van der Woude, L. A. van Es, and M. R. Daha. 1991. Interleukin 2 mediates stimulation of complement $\mathrm{C} 3$ biosynthesis in human proximal tubular epithelial cells. J. Clin. Invest. 88:379-384.

15. Bohle, A., S. Mackensen-Haen, and H. V. Gise. 1987. Significance of tubulointerstitial changes in the renal cortex for the excretory function and concentration ability of the kidney: a morphometric contribution. Am. J. Nephrol. 7:421-433.

16. Border, W. A., and E. Ruoslahti. 1992. Transforming growth factor- $\beta$ in disease: the dark side of tissue repair. J. Clin. Invest. 90:1-7.

17. Horii, Y., A. Muraguchi, M. Iwano, T. Matsuda, T. Hirayama, H. Yamada, Y. Fuji, K. Dohi, H. Ishikawa, Y. Ohmoto, et al. 1989. Involvement of IL-6 in mesangial proliferative glomerulonephritis. J. Immunol. 143:3949-3955.

18. Nath, K. A., M. K. Hostetter, and T. H. Hostetter. 1989. Ammonia-complement interaction in the pathogenesis of progressive renal injury. Kidney Int. 36:S-52-S-54.

19. Gordon, D. L., R. A. Krueger, P. G. Quie, and M. K. Hostetter. 1985. Amidation of $\mathrm{C} 3$ at the thiolester site: stimulation of chemiluminescence and phagocytosis by a new inflammatory mediator. J. Immunol. 134:3339-3345. 